\title{
Novel Sources of Resistance to Phytophthora capsici on Pepper (Capsicum sp.) Landraces from Mexico
}

\author{
Jesús Enrique Retes-Manjarrez (iD 1,2*, Walter Arturo Rubio-Aragón ${ }^{1}$, Isidro Márques-Zequera ${ }^{3}$, \\ Isabel Cruz-Lachica ${ }^{3}$, Raymundo Saúl García-Estrada ${ }^{3}$, and Ousmane $\mathrm{Sy}^{\mathbf{4}}$ \\ ${ }^{l}$ Facultad de Agronomía, Universidad Autónoma de Sinaloa, Carretera Culiacán-Eldorado, km 17.5, C.P. 80000, \\ Culiacán, Sinaloa, México \\ ${ }^{2}$ Wholesum, Carretera Hermosillo-Nogales, km 216, C.P. 84134, Colonia Los Janos, Imuris Sonora, México \\ ${ }^{3}$ Centro de Investigación en Alimentación y Desarrollo, A. C. Carretera Culiacán-El Dorado, km 5.5, Culiacán Sinaloa, \\ México \\ ${ }^{4}$ Independent Researcher, Dakar, Senegal, C.P. 10200, México
}

(Received on July 16, 2020; Revised on September 29, 2020; Accepted on November 2, 2020)

Phytophthora capsici Leonian is a major pathogen of pepper worldwide and few resistance sources to this pathogen have been identified so far. The goals of this study were to identify new sources of resistance against $P$. capsici in Capsicum landraces and analyze the relationship between the resistance indicator of plant symptoms and some plant phenotype parameters of plant height, stem width, leaf length and leaf width. Thirtytwo landraces of pepper were collected from fourteen states in Mexico. From each population, 36 plants were inoculated with 10,000 zoospores of $P$. capsici under controlled conditions. This experiment was repeated twice. Out of the 32 landraces, six showed high level of resistance, four showed intermediate resistance and five showed low level of resistance when compared with the susceptible control 'Bravo' and the resistant control 'CM334', indicating that these landraces are promising novel sources of resistance to $P$. capsici. There was no correlation between the symptoms and plant phenotype parameters. However, these parameters were not af-

*Corresponding author.

Phone) +52-6671272018, FAX) +52-6323260848

E-mail) retesmje@hotmail.com

ORCID

Jesús Enrique Retes-Manjarrez

https://orcid.org/0000-0002-5151-6555

(c) This is an Open Access article distributed under the terms of the Creative Commons Attribution Non-Commercial License (http:// creativecommons.org/licenses/by-nc/4.0) which permits unrestricted noncommercial use, distribution, and reproduction in any medium, provided the original work is properly cited.

Articles can be freely viewed online at www.ppjonline.org. fected in the group classified as highly resistant, indicating that $P$. capsici does not affect the growing of these resistant pepper landraces. The other resistant groups were significantly affected in a differently manner regarding their phenotype, indicating that this pathogen reduce their growth in different ways. This study reports novel resistance sources with great potential that could be used in breeding programs to develop new pepper cultivars with durable resistance to $P$. capsici.

Keywords : Capsicum annuum, genetic resources, pepper breeding programs, Phytophthora capsici, resistance level

Handling Editor : Cecile Segonzac

Disease epidemics caused by the oomycete Phytophthora capsici Leonian are a major challenge for chili pepper (Capsicum annuum Linneo, $C$. chinense Jacq, $C$. frutescens Linneo, C. baccatum Linneo, and C. pubescens Ruiz and Pavon) growers worldwide (Sun et al., 2008; Thompson et al., 1994). The pathogen causes foliar blight, root rot, fruit rot and crown rot syndromes, and is particularly severe under flood conditions, often resulting in total crop losses (Erwin and Ribeiro, 1996; Lamour et al., 2011; Mansfeld et al., 2017; Sy et al., 2005).

Current strategies for managing $P$. capsici in commercial chili pepper production fields rely heavily on chemical fungicides (Jackson et al., 2012; Lamour and Hausbeck, 2000; Matheron and Porchas, 2000; Sanogo and Ji, 2013), cultural management practices such as crop rotation, soil-water management (Hausbeck and Lamour, 2004) and planting 
resistant varieties (Barchenger et al., 2018). The use of resistant varieties is seen as the best option thanks to its positive impact on the environment and its economic benefits. However, few resistant cultivars have been reported so far (Barchenger et al., 2018). Additionally, the population structure of the pathogen is highly variable, and all available commercial cultivars reportedly showed low levels of resistance to this pathogen because of the complexity of the resistance mechanisms (Dunn et al., 2014; Granke et al., 2011; Krasnow et al., 2017). Therefore, the identification of novel sources of resistance to help develop new cultivars with durable resistance towards this pathogen would be highly desirable.

Few pepper sources to $P$. capsici have been identified so far (Barksdale et al., 1984; Guerrero-Moreno and Laborde, 1980; Matsuoka, 1984; Peter et al., 1984; Saini and Sharma, 1978; Smith et al., 1967). These sources have been identified in the $C$. annuиm species. Some examples are 'Criollo de Morelos-334' (CM334), 'PI 201232', and 'PI 201234 85' from Mexico, 'AC2258' from Central America, and 'Perennial' from India. From these sources, 'CM334' has been shown to have the highest level of resistance (Quirin et al., 2005). These resistant sources often present linkage drag for low yield and for other undesirable fruit qualities (Barchenger et al., 2018). Based on previous studies, we hypothesized that Capsicum landraces collected in Mexico could potentially possess high and varying levels of resistance to $P$. capsici, Mexico being the center of origin and domestication of Capsicum species (Carrizo-García et al., 2016; Hernández-Verdugo et al., 1999). Therefore, the goals of the present study were to (1) identify other sources of resistance against $P$. capsici and (2) analyze the relationship between the resistance indicator of plant symptoms and some plant phenotype parameters. This in an overall effort to help support pepper breeding programs worldwide, a global pepper industry currently valued at 31261 million dollars annually (Food and Agriculture Organization of the United Nations, 2019).

\section{Materials and Methods}

Plant materials. Thirty-two accessions of Capsicum collected in fourteen states from Mexico (Sinaloa, Nayarit, Durango, Jalisco, San Luis Potosi, Guanajuato, Queretaro, Michoacan, Hidalgo, Guerrero, Oaxaca, Estado de Mexico, Veracruz, and Puebla in Mexico) were evalauted (Fig. 1).

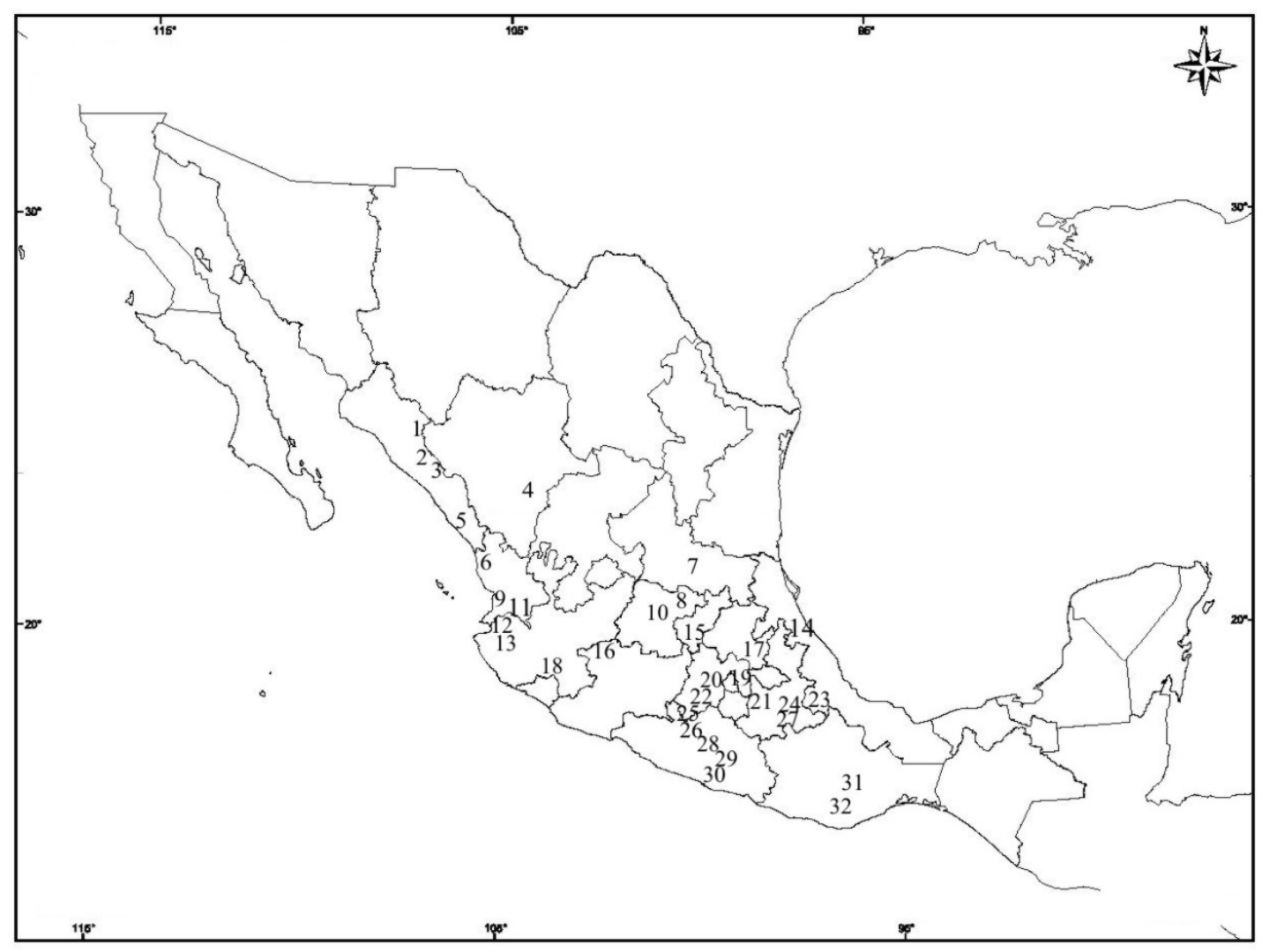

Fig. 1. Geographic location of the 32 landrace populations of Capsicum spp. collected in 14 states of Mexico. 
For seed extraction, 15 plants were sampled per accession and seeds were extracted from mature fruits. The accessions of pepper collected belonged to the $C$. annuum and $C$. pubescens (International Plant Genetic Resources Institute, 1995). The C. annuum cultivar 'Bravo' a Jalapeño type (Shamrock, Salinas, CA, USA) and the accession 'CM334' were used as susceptible control and resistant control, respectively. Seeds were disinfected with sodium triphosphate at $10 \%$ for $30 \mathrm{~min}$ and dried at room temperature for three days before sowing.

Inoculum preparation and phenotyping. Inoculum for the experiment was prepared using a virulent isolate of $P$. capsici (provided by Dr. Raymundo García-Estrada, CIAD institute of Sinaloa) grown on 14\% V8 agar plates (140 ml $\mathrm{V} 8$ juice, $3 \mathrm{~g} \mathrm{CaCO}_{3}, 16 \mathrm{~g}$ agar per liter) agar petri dishes $(100 \times 15 \mathrm{~mm})$ under constant fluorescent light at $28^{\circ} \mathrm{C}$ for 10 days.

Two experiments were conducted, the first one in February and the same experiment was repeated in March of the same year (2019). Seeds were germinated and grown individually in 4-inch pots containing sterile (autoclaved) mixture of soil and sand (2:1), in a greenhouse. The Bosland and Lindsey's (1991) method was used to screen for $P$. capsici root rot. Plant trays with drainage holes were placed into trays filled with water. Each plant (2-4 true leaves) cell received $5 \mathrm{~mL}$ of inoculum (2,000 zoospores/ $\mathrm{ml}$ ). The flooded root zone condition was maintained for two days before the plant trays were removed and placed on a greenhouse bench. The experiment was established as a completely randomized design with 34 treatments, each landrace being considered as a treatment. Each treatment was replicated thrice with twelve plants per treatment $(n=$ 36 each). Twenty-four plants of each landrace also received plain water to serve as a non-inoculated control. For scoring, a 1-9 rating scale from Padley et al. (2008) was used with $1=$ dead plant, $3=$ complete collapse with severe wilting and lesion up to the cotyledons causing constriction at the base, $5=$ lesion has expanded $1-2 \mathrm{~cm}$ up from the base of the plant, $7=$ small brown lesion at base of the stem, and $9=$ no symptoms. Plants with a score of 7 or 9 were considered resistant, and plants with a score lower than 7 were considered susceptible. Final disease severity was recorded at 28 days after inoculation (dai). The experiment was repeated twice, under insect-proof greenhouse conditions. Greenhouse temperatures varied between 20 and $32^{\circ} \mathrm{C}$ during the period of the study.

Plant growth parameters such as plant height (from the base to the top of the plant), stem witdth (at base level), leaf length and leaf width (first leaf expanded from the top of the plant) were equally recorded from all the plants used in these experiments at 28 dai.

Data analysis. The data from the resistance indicator (scale severity) did not comply with the statistical assumptions of normality and homogeneity of variances; therefore, they were subjected to a nonparametric variance analysis with the Kruskal-Wallis and Dunn medians tests to determine significant differences between landraces $(P \leq 0.05)$. To analyze the correlations between resistance indicator and plant growth parameters, a separate analysis was conducted combining data from the landraces used in the two experiments. Data could be combined since there were no significant differences between the two experiments for all the plant growth parameters considered. Because the data from the plant phenotype indicators (plant height, stem width, leaf length and leaf width) showed a normal distribution and an equal homogeneity of variance, these were assessed via parametric variance analysis and Tukey test to determine the significance of differences between landraces $(P \leq 0.05)$. The Spearman correlation analysis $(r)$ was used to assess $P$. capsici symptoms and the plant growth parameters mentioned above. All statistical analysis was performed using SAS statistical package (version 8.0, SAS institute, Cary, NC, USA).

\section{Results}

Resistance assays. Data obtained in both resistance assays were not statistically different and could therefore be combined.

The results showed four groups with different levels of resistance to $P$. capsici when compared with the susceptible control 'Bravo' and the resistant control 'CM334' (Fig. 2 ). The four groups were the high resistance, intermediate resistance, low resistance and susceptible. The three resistant groups showed significantly less severe symptoms (Fig. 2A) and more resistance (Fig. 2B) to this pathogen as compared to the susceptible control $(P \leq 0.001)$. However, the accessions in the intermediate and the low resistance group were significantly more affected than the resistant control $(P \leq 0.001)$ (Fig. 2). Interestingly, the accessions that belonged to the highly resistant group did not show any significant severe symptoms and resistance level when compared with the resistant control 'CM334' $(P>0.05)$ (Fig. 2).

In both experiments, all genotypes tested against the $P$. capsici isolate showed symptoms of this pathogen including the resistant control 'CM334', although there were significant $(P \leq 0.001)$ differences among genotypes re- 


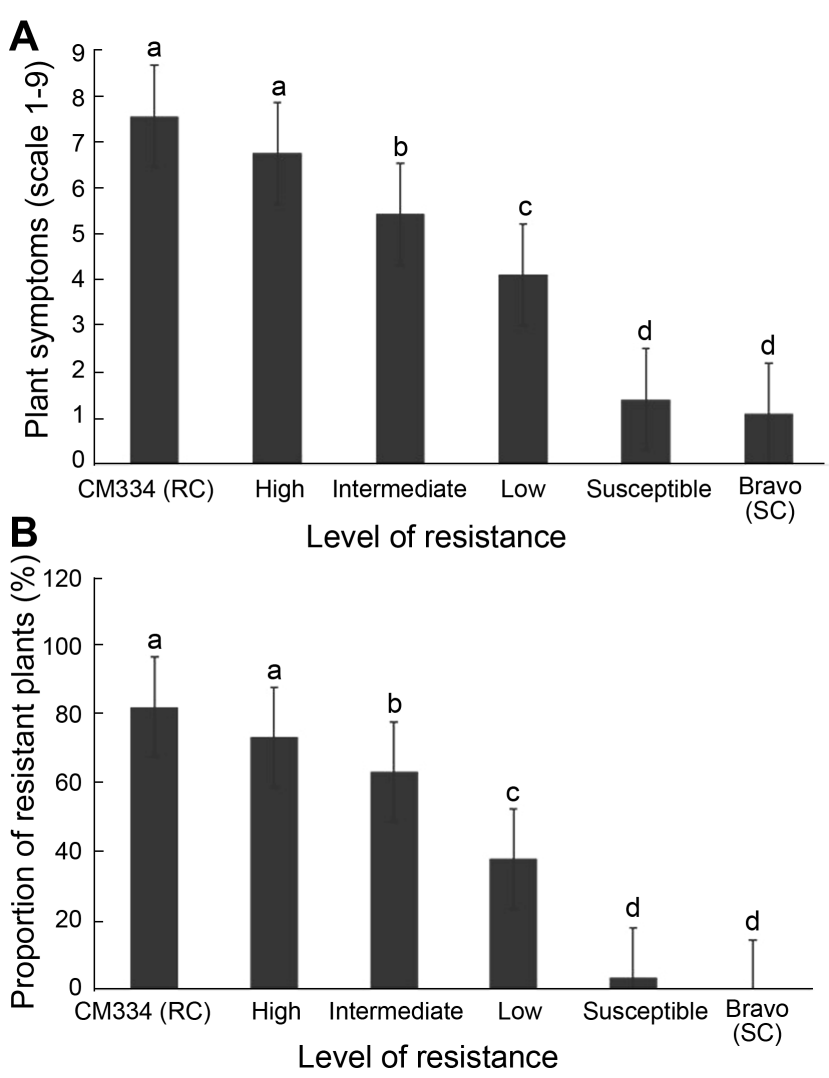

Fig. 2. Response of four groups of pepper landraces and two accessions (one susceptible, and one resistant) to Phytophthora capsici under greenhouse conditions. (A) Plant symptoms (scale 1 to 9 as described above). (B) Proportion of resistant plants (number of resistance plants/ total of plants tested). Means with same letter indicate no significance difference.

garding severity of symptoms (Table 1). Fifteen accessions had different levels of resistance as they had significantly lower symptoms and a higher number of resistant plants when compared with the susceptible control. Four $C$. annuum (FA19, FA20, FA22, and FA23) and two C. pubescens (FA08 and FA01) accessions were considered highly resistant as they averaged $73.5 \%$ of resistant plants and did not have significant differences when compared with the resistant control 'CM334' with $82 \%$ resistance $(P \leq 0.001)$ (Table 1). Two $C$. annuum (FA30 and FA15) and two $C$. pubescens (FA09 and FA05) accessions showed intermediate level of resistance and two C. pubescens (FA03 and FA04) and three $C$. annuum (FA12, FA18, and FA25) accessions showed low level of resistance $(P \leq 0.001)$ (Table 1). As for the remainder of the accessions, there were considered as susceptible since they did not statistically differ from the susceptible control $(P \leq 0.001)$ (Table 1). All re-
Table 1. Response of 32 landraces populations and two accessions (one susceptible and one resistant) of Capsicum spp. to Phytophthora capsici under greenhouse conditions

\begin{tabular}{|c|c|c|c|c|c|}
\hline $\mathrm{P}$ & M & PS & PRP (\%) & $\mathrm{RS}$ & LR \\
\hline SC (Bravo) & Jalapeño & $1.0 \mathrm{i}$ & 0 & 1 & $\mathrm{~S}$ \\
\hline FA17 & Piquin & $1.0 \mathrm{i}$ & 0 & 1 & S \\
\hline FA21 & Piquin & $1.0 \mathrm{i}$ & 0 & 1 & S \\
\hline FA11 & Guajillo & $1.0 \mathrm{i}$ & 0 & 1 & S \\
\hline FA14 & Guajillo & $1.0 \mathrm{i}$ & 0 & 1 & S \\
\hline FA29 & Jalapeño & $1.0 \mathrm{i}$ & 0 & 1 & S \\
\hline FA31 & Cascabel & $1.0 \mathrm{i}$ & 0 & 1 & $\mathrm{~S}$ \\
\hline FA32 & Verde & $1.0 \mathrm{i}$ & 0 & 1 & $\mathrm{~S}$ \\
\hline FA06 & Ancho & $1.0 \mathrm{i}$ & 0 & $1-3$ & S \\
\hline FA13 & Verde & $1.1 \mathrm{i}$ & 0 & $1-3$ & S \\
\hline FA16 & Piquin & $1.3 \mathrm{i}$ & 0 & $1-3$ & S \\
\hline FA02 & Canica & $1.4 \mathrm{i}$ & 0 & $1-3$ & S \\
\hline FA27 & Piquin & $1.4 \mathrm{i}$ & 0 & $1-5$ & $\mathrm{~S}$ \\
\hline FA28 & Manzano & $2.0 \mathrm{hi}$ & 0 & $1-5$ & $\mathrm{~S}$ \\
\hline FA24 & Piquin & $2.3 \mathrm{hi}$ & 0 & $1-5$ & $\mathrm{~S}$ \\
\hline FA26 & Piquin & $2.4 \mathrm{hi}$ & 0 & $1-5$ & $\mathrm{~S}$ \\
\hline FA07 & Cascabel & $2.5 \mathrm{hi}$ & 0 & $1-5$ & $\mathrm{~S}$ \\
\hline FA10 & Pasilla & $2.6 \mathrm{hi}$ & 16 & $1-7$ & S \\
\hline FA25 & Piquin & $3.2 \mathrm{fg}$ & 22 & $1-9$ & $\mathrm{~L}$ \\
\hline FA18 & Piquin & $3.7 \mathrm{f}$ & 26 & $1-9$ & $\mathrm{~L}$ \\
\hline FA12 & Cola de rata & $4.0 \mathrm{f}$ & 34 & $1-9$ & $\mathrm{~L}$ \\
\hline FA04 & Manzano & $5.0 \mathrm{de}$ & 51 & $1-9$ & $\mathrm{~L}$ \\
\hline FA03 & Manzano & $5.5 \mathrm{~d}$ & 57 & $1-9$ & $\mathrm{~L}$ \\
\hline FA05 & Manzano & $5.7 \mathrm{c}$ & 56 & $1-9$ & I \\
\hline FA09 & Manzano & $5.7 \mathrm{c}$ & 65 & $1-9$ & I \\
\hline FA15 & Piquin & $5.8 \mathrm{c}$ & 64 & $1-9$ & I \\
\hline FA30 & Pasilla & $6.1 \mathrm{bc}$ & 68 & $1-9$ & I \\
\hline FA23 & Piquin & $6.6 \mathrm{ab}$ & 71 & $1-9$ & $\mathrm{H}$ \\
\hline FA01 & Manzano & $6.8 \mathrm{ab}$ & 73 & $1-9$ & $\mathrm{H}$ \\
\hline FA22 & Piquin & $6.8 \mathrm{ab}$ & 74 & $1-9$ & $\mathrm{H}$ \\
\hline FA20 & Jalapeño & $6.8 \mathrm{ab}$ & 76 & $1-9$ & $\mathrm{H}$ \\
\hline FA19 & Jalapeño & $6.9 \mathrm{ab}$ & 76 & $1-9$ & $\mathrm{H}$ \\
\hline FA08 & Manzano & $7.1 \mathrm{ab}$ & 70 & $1-9$ & $\mathrm{H}$ \\
\hline $\mathrm{RC}$ (CM334) & Jalapeño & $7.6 \mathrm{a}$ & 82 & $1-9$ & $\mathrm{H}$ \\
\hline
\end{tabular}

Means with same letter indicate no significance difference.

P, population; M, morphotype; PS, plant symptoms (scale 1 to 9 where 1 = plant dead, 3 = plant has completely collapsed with severe wilting present and lesion has progressed up to the cotyledons causing constriction at the base, $5=$ lesion has expanded $1-2 \mathrm{~cm}$ up from the base of the plant, $7=$ small brown lesion at base of stem, and $9=$ no symptoms); PRP, proportion of resistant plants (number of resistance plants/total of plants tested); RS, range of symptoms; LR, level of resistance; S, susceptible; L, low resistance; I, intermediate resistance; $\mathrm{H}$, high resistance

sistant plants matured and set fruits, and the considered as susceptible died at different time and not produced fruits. 


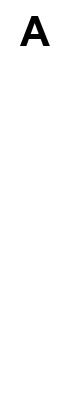

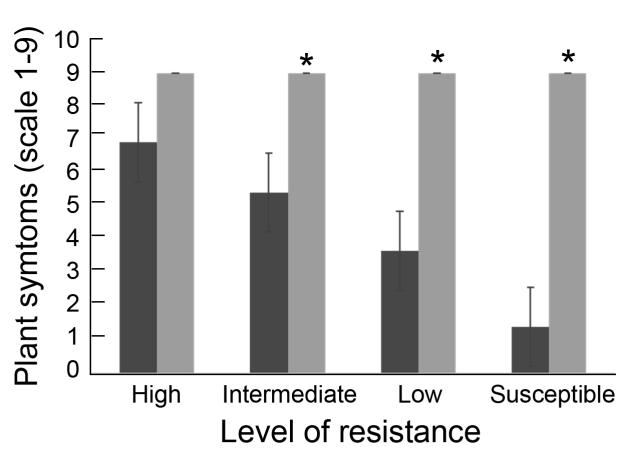
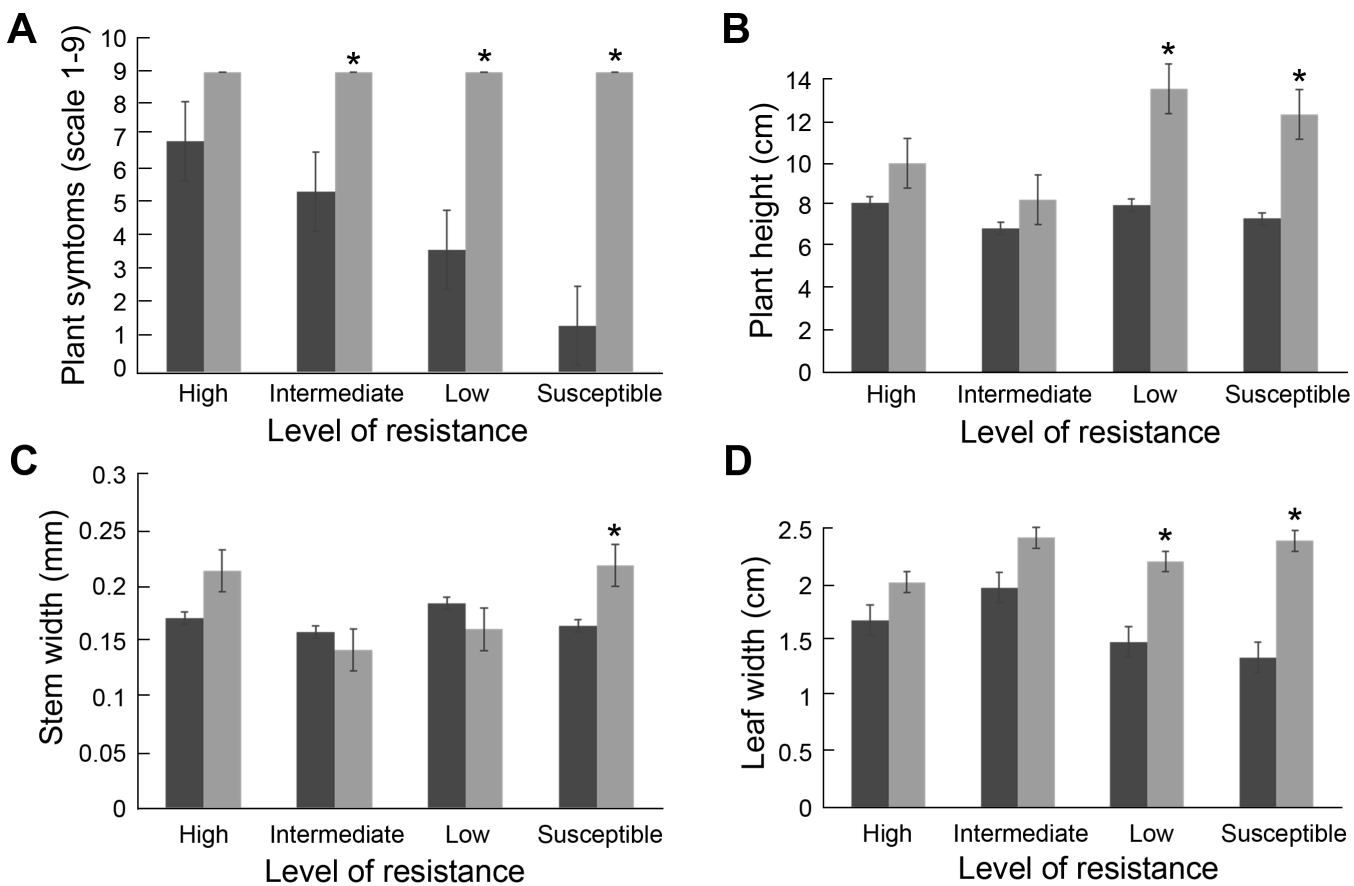

D
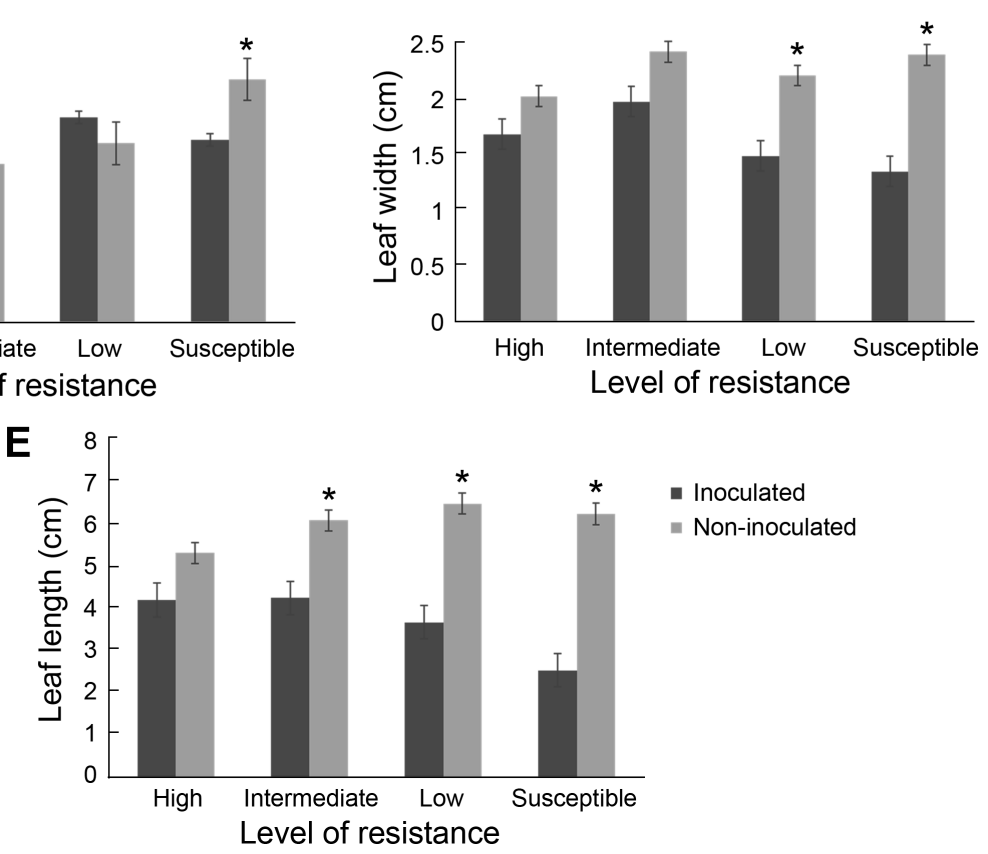

Fig. 3. Response of four groups of pepper landraces to Phytophthora capsici inoculations on the resistance and phenotypic plant parameters of Capsicum spp. under greenhouse conditions. (A) Plant symptoms (scale 1 to 9 as described above). (B) Plant height (cm). (C) Stem width $(\mathrm{cm})$. (D) Leaf width $(\mathrm{cm})$. (E) Leaf length $(\mathrm{cm})$. Asterisks indicate a significant difference between inoculated and noninoculated controls 28 days after inoculation $(P \leq 0.05)$.

Interactions between plant resistance parameter, and growth parameters. There was no correlation between plant resistance and plant growth parameters such as plant height, stem width, leaves length, and leaves width measured 28 dai $(P>0.05)$.

There were significantly differences for all the plant growth and resistance parameters in combined results between inoculated and non-inoculated plants 28 dpi $(P$ $\leq 0.05$ ) (Fig. 3). Plant symptoms was significantly higher only in the group with low and intermediate resistance, as well as in the susceptible control (Fig. 3A). Plant height was significantly reduced only in the group with low resistance and in the susceptible control (Fig. 3B). Stem width was significantly affected only in the susceptible control (Fig. 3C), whereas the leaf width had significant reductions in the susceptible control and in the group with low levels of resistance (Fig. 3D). Leaf length was not significantly affected only in the group with high level of resistance to this pathogen (Fig. 3E).

\section{Discussion}

Phytophthora capsici is one of the most devastating pathogen for Capsicum spp. production worldwide and current management strategies are not effective (Barchenger et al., 2018). The population structure of the pathogen is highly variable, and very few resistance sources are available (Barchenger et al., 2018).

Based on the plant symptoms severity and the level of resistance when compared with the susceptible cultivar 
'Bravo' and the resistant accession 'CM334' considered to have the highest known level of resistance (Candole et al., 2010; Mo et al., 2014), three resistance groups were identified. These results indicate that pepper landraces populations from Mexico could potentially have different genetic background and profiles that could be used in breeding programs.

All landraces in this study showed some symptoms of $P$. capsici damage, including the resistant control, proving that no immunity reaction is involved. This result agrees with Naegele et al. (2014) who also indicated that even the accession 'CM334' could show susceptibility under high pressure of inoculum and/or different strains of $P$. capsici.

Out of the 32 landraces used in this study, six showed high levels of resistance (four C. annuum and two C. pubescens), four showed intermediate levels of resistance (two $C$. annuum and two C. pubescens) and five showed low levels of resistance (two C. pubescens and three C. annuum). The different levels of resistance found in these Capsicum populations can be due to different resistance genes and multiple genes interactions with additive or epistatic effects (Lefebvre and Palloix, 1996; Sy et al., 2005). These results were confirmed when the test was repeated a second time, indicating that these landraces are promising sources of resistance to $P$. capsici.

Additionally, this study shows some resistance sources in different pepper morphotypes that have not yet been reported so far, such as the pasilla, piquin and cola de rata morphotypes in the $C$. annuum and also in the manzano morphotype from the $C$. pubescens. These pepper morphotypes could potentially present different genetic background with simpler resistance mechanisms and the absence of negative linkage drags (Barchenger et al., 2018). Previous studies showed that Mexican pepper populations possess different levels of resistance to major pathogens such as virus (Retes-Manjarrez et al., 2016, 2017, 2018), and nematodes (Carrillo-Fasio et al., 2020). Based on these results, these resistant populations could serve as potential candidates to help better characterize the resistance to $P$. capsici, with the ultimate goal to develop resistant commercials cultivars.

There was no correlation among morphotypes, levels of resistance and geographical location, indicating that the resistance observed on these morphotypes is independent of these factors. These differences must be because landrace populations of Capsicum spp. have been in contact with $P$. capsici in the same geographic area in Mexico, at least during the last century, indicating that these pepper populations have been exposed to the selective pressure imposed by this pathogen. This constitutes a plausible explanation for the different levels of resistance to this pathogen that has been detected in these landrace pepper populations. At the same time, landrace populations of pepper have not been sufficiently explored as a source of genetic resistance to $P$. capsici. For this reason, it must be incorporated in future breeding programs to increase $P$. capsici resistance in pepper and to bring new variability that could contribute to improving other agronomical traits such as yield and vigor.

The landrace pepper populations collected in Mexico showed a wide variation in their resistance levels to $P$. capsici. This wide variability enabled us to find and select plants with different resistance levels to this pathogen. These results agree with the wide variation observed in landrace and wild peppers reported in this country (Carrillo-Fasio et al., 2020; Hernández-Verdugo et al., 2006; Pacheco-Olvera et al., 2012; Retes-Manjarrez et al., 2016, 2017, 2018) regarding different morphological traits and different resistance levels to different plant pathogens.

Plant inoculation with $P$. capsici did not have a negative effect on the plant resistance parameter (plant symptoms) and the plant growth parameters (plant height, stem width, leaf width and leaf length) of the group classified as highly resistant to this pathogen, indicating that the presence of this pathogen in their root system with the optimal conditions of the pathogen to infect does not affect the growing of these plants. However, in the groups with low and intermediate resistance was observed that infection of these pepper landraces by the pathogen affected their growth in different ways for different landraces, indicating that this pathogen reduces their plant growth in different ways. These results agree with those reported by Gisbert et al. (2010), who reported a significant reduction in the growth of inoculated plants with $P$. capsici. Due to plant growth is linked to high yield (Carrillo-Fasio et al., 2020), these results indicate that $P$. capsici reduces the productivity of pepper plants by affecting their height, stem width, leaf width and leaf length. These results indicate that the six populations (FA23, FA10, FA20, FA22, FA19, and FA08) included in this group are potential sources of resistance to $P$. capsici with high productivity by not manifesting severe disease symptoms and negative affectations on its growth parameters. Based on these results, these resistance populations are candidates to be used in further studies to characterize resistance traits and its inheritance to design a genetic model for its introgression into commercials genetic background.

The resistant landrace populations identified in the present study are important sources of resistance that could complement new breeding programs to develop resistant cultivars to multiple $P$. capsici isolates with high yield and fruit quality. The similar results on the two consecutive as- 
says indicate that these resistant sources are comparatively steady for this pathogen. Additionally, these sources of resistance could bring new sources of variation that could be used to improve in parallel the yield and fruit quality of pepper crops.

\section{Conflicts of Interest}

No potential conflict of interest relevant to this article was reported.

\section{Acknowledgments}

The authors thanks FitoCiencia for the support provided to this research.

\section{References}

Barchenger, D. W., Lamour, K. H. and Bosland, P. W. 2018. Challenges and strategies for breeding resistance in Capsicum annuum to the multifarious pathogen, Phytophthora capsici. Front. Plant Sci. 9:628.

Barksdale, T. H., Papavizas, G. C. and Johnston, S. A. 1984. Resistance to foliar blight and crown rot of pepper caused by Phytophthora capsici. Plant Dis. 68:506-509.

Bosland, P. W. and Lindsey, D. L. 1991. A seedling screen for Phytophthora root rot of pepper, Capsicum annuum. Plant Dis. 75:1048-1050.

Candole, B. L., Conner, P. J. and Ji, P. 2010. Screening Capsicum annuum accessions for resistance to six isolates of Phytophthora capsici. HortScience 45:254-259.

Carrillo-Fasio, J. A., Martínez-Gallardo, J. A., Ayala-Tafoya, F., López-Orona, C. A., Allende-Molar, R. and Retes-Manjarrez, J. E. 2020. Screening for resistance to Meloidogyne enterolobii in Capsicum annuum landraces from Mexico. Plant Dis. 104:817-822.

Carrizo García, C., Barfuss, M. H. J., Sehr, E. M., Barboza, G. E., Samuel, R., Moscone, E. A. and Ehrendorfer, F. 2016. Phylogenetic relationships, diversification and expansion of chili peppers (Capsicum, Solanaceae). Ann. Bot. 118:35-51.

Dunn, A. R., Lange, H. W. and Smart, C. D. 2014. Evaluation of commercial bell pepper cultivars for resistance to Phytophthora blight (Phytophthora capsici). Plant Health Prog. 15:19-24.

Erwin, D. C. and Ribeiro, O. K. 1996. Phytophthora diseases worldwide. American Phytopathological Society, St. Paul, MN, USA. 562 pp.

Food and Agriculture Organization of the United Nations. 2019. Statistics Division. URL http://faostat3.fao.org/ [10 April 2020].

Gisbert, C., Sánchez-Torres, P., Raigón, M. D. and Nuez, F. 2010. Phytophthora capsici resistance evaluation in pepper hybrids: agronomic performance and fruit quality of pepper grafted plants. J. Food Agric. Environ. 8:116-121.

Granke, L. L., Quesada-Ocampo, L. M. and Hausbeck, M. K. 2011. Variation in phenotypic characteristics of Phytophthora capsici isolates from a worldwide collection. Plant Dis. 95:1080-1088.

Guerrero-Moreno, A. and Laborde, J. A. 1980. Current status of pepper breeding for resistance to Phytophthora capsici in Mexico. In: Synopsis of the IVth Meeting of the Capsicum Working Group of Eucarpia, pp. 52-56. Institute for Horticultural Plant Breeding (IVT), Wageningen, The Netherlands.

Hausbeck, M. K. and Lamour, K. H. 2004. Phytophthora capsici on vegetable crops: research progress and management challenges. Plant Dis. 88:1292-1303.

Hernández-Verdugo, S., Aranda-Dávila, P. and Oyama, K. 1999. Review of taxonomy, origin and domestication of the genus Capsicum. Bol. Soc. Bot. Méx. 64:65-84.

Hernández-Verdugo, S., González-Rodríguez, A., Sánchez-Peña, P., Casas, A. and Oyama, K. 2006. Estructura y diferenciación genética de poblaciones silvestres y domesticadas de chile del Noroeste de México analizada con isoenzimas y RAPDs. Rev. Fitotec. Mex. 29:25-29.

International Plant Genetic Resources Institute. 1995. Descriptors for Capsicum (Capsicum spp.). URL https://www. bioversityinternational.org/fileadmin/_migrated/uploads/tx_ news/Descriptors_for_capsicum_Capsicum_spp._345.pdf [10 April 2020].

Jackson, K. L., Yin, J. and Ji, P. 2012. Sensitivity of Phytophthora capsici on vegetable crops in Georgia to mandipropamid, dimethomorph, and cyazofamid. Plant Dis. 96:1337-1342.

Krasnow, C. S., Wyenandt, A. A., Kline, W. L., Carey, J. B. and Hausbeck, M. K. 2017. Evaluation of pepper root rot resistance in an integrated Phytophthora blight management program. HortTechnology 27:408-415.

Lamour, K. H. and Hausbeck, M. K. 2000. Mefenoxam insensitivity and the sexual stage of Phytophthora capsici in Michigan cucurbit fields. Phytopathology 90:396-400.

Lamour, K. H., Stam, R., Jupe, J. and Huitema, E. 2011. The oomycete broad host-range pathogen Phytophthora capsici. Mol. Plant Pathol. 13:329-337.

Lefebvre, V. and Palloix, A. 1996. Both epistatic and additive effects of QTLs are involved in polygenic induced resistance to disease: a case study, the interaction pepper-Phytophthora capsici Leonian. Theor. Appl. Genet. 93:503-511.

Mansfeld, B. N., Colle, M., Kang, Y., Jones, A. D. and Grumet, R. 2017. Transcriptomic and metabolomic analyses of cucumber fruit peels reveal a developmental increase in terpenoid glycosides associated with age-related resistance to Phytophthora capsici. Hortic. Res. 4:17022.

Matheron, M. E. and Porchas, M. 2000. Comparison of five fungicides on development of root, crown, and fruit rot of chile pepper and recovery of Phytophthora capsici from soil. Plant Dis. 84:1038-1043.

Matsuoka, K. 1984. Melhoramento de pimentão e pimenta visan- 
do a resistência a doenças fungicas. Inf. Agropecu. 10:49-52.

Mo, H., Kim, S., Wai, K. P. P., Siddique, M. I., Yoo, H. and Kim, B.-S. 2014. New sources of resistance to Phytophthora capsici in Capsicum spp. Hort. Environ. Biotechnol. 55:50-55.

Naegele, R. P., Ashrafi, H., Hill, T. A., Chin-Wo, S. R., Van Deynze, A. E. and Hausbeck, M. K. 2014. QTL mapping of fruit rot resistance to the plant pathogen Phytophthora capsici in a recombinant inbred line Capsicum annuum population. Phytopathology 104:479-483.

Pacheco-Olvera, A., Hernández-Verdugo, S., Rocha-Ramírez, V., González-Rodríguez, A. and Oyama, K. 2012. Genetic diversity and structure of pepper (Capsicum annuum L.) from Northwestern Mexico analyzed by microsatellite markers. Crop Sci. 52:231-241.

Padley, L. D., Kabelka, E. A., Roberts, P. D. and French, R. 2008. Evaluation of Curcurbita pepo accessions for crown rot resistance to isolates of Phytophthora capsici. HortScience 43:1996-1999.

Peter, K.V., Goth, R. W. and Webb. R. E. 1984. Indian hot peppers as new sources of resistance to bacterial wilt, Phytophthora root rot and root knot nematode. HortScience 19:277278.

Quirin, E. A., Ogundiwin, E. A., Prince, J. P., Mazourek, M., Briggs, M. O., Chlanda, T. S., Kim, K.-T., Falise, M., Kang, B.-C. and Jahn, M. M. 2005. Development of sequence characterized amplified region (SCAR) primers for the detection of Phyto.5.2, a major QTL for resistance to Phytophthora capsici Leon. in pepper. Theor. Appl. Genet. 110:605-612.

Retes-Manjarrez, J. E., Hernández-Verdugo, S., Evrard, A. and Garzón-Tiznado, J. A. 2017. Heritability of the resistance to pepper huasteco yellow vein virus in wild genotypes of Capsicum annuum. Euphytica 213:275.
Retes-Manjarrez, J. E., Hernández-Verdugo, S., Pariaud, B., Hernández-Espinal, L. A., Parra-Terraza, S., Trejo-Saavedra, D. L., Rivera-Bustamante, R. F. and Garzón-Tiznado, J. A. 2018. Resistance to pepper huasteco yellow vein virus and its heritability in wild genotypes of Capsicum annuum. Bot. Sci. 96:52-62.

Retes-Manjarrez, J. E., Hernández-Verdugo, S., Pariaud, B., Melgoza-Villagómez, C. M., Pacheco-Olvera, A., Parra-Terraza, S. and Garzón-Tiznado, J. A. 2016. Detección de resistencia al virus huasteco vena amarilla del chile y su heredabilidad en genotipos silvestres de Capsicum annuum L. Interciencia 41:541-547.

Saini, S. S. and Sharma, P. P. 1978. Inheritance of resistance to fruit rot (Phytophthora capsici Leon.) and induction resistance in bell pepper (Capsicum annuum L.). Euphytica 27:721-723.

Sanogo, S. and Ji, P. 2013. Water management in relation to control of Phytophthora capsici in vegetable crops. Agric. Water Manag. 129:113-119.

Smith, P. G., Kimble, K. A., Grogan, R. G. and Millet, A. H. 1967. Inheritance of resistance in peppers to Phytophthora root rot. Phytopathology 57:377-379.

Sun, W. X., Jia, Y. J., O’Neill, N. R., Feng, B. Z. H. and Zhang, X. G. 2008. Genetic diversity in Phytophthora capsici from eastern China. Can. J. Plant Pathol. 30:414-424.

Sy, O., Steiner, R. and Bosland, P. W. 2005. Inheritance of Phytophthora stem blight resistance as compared to Phytophthora root rot and Phytophthora foliar blight resistance in Capsicum annuum L. J. Am. Hortic. Soc. 130:75-78.

Thompson, A. H., Uys, M. D. R. and Botha, W. J. 1994. Phytophthora capsici (Oomycota: Fungi), a first report from South Africa. S. Afr. J. Bot. 60:257-260. 